\title{
Synthesis and Characterization of Hydroxyapatite Ceramics \\ Organofunctionalized with ATP (Adenosine Triphosphate)
}

Khaled Hammami ${ }^{a}$, Jihene Elloumi ${ }^{b}$, Sami Aifa ${ }^{b}$, Christophe Drouet ${ }^{c}$, Hafed El Feki ${ }^{a^{*}}$

a Laboratoire de L'Environnement et de Sciences de Matériaux (MESLAB), Faculté des sciences de Sfax, BP 8023018 Sfax, Tunisia.

E-mail:mekhaled8@gmail.com

E-mail:hafed.elfeki@yahoo.fr

b Centre de Biotechnologie de Sfax, Route de Sidi Mansour Km 6 BP 1177, 3018 Sfax, Tunisia .

elloumijihene@yahoo.fr

sami.aifa@cbs.rnrt.tn

c CIRIMAT Carnot Institute, University of Toulouse, UMR CNRS/INPT/UPS 5085, Ensiacet, 4 allée Emile Monso, 31030 Toulouse cedex 4, France.

christophe.drouet@ensiacet.fr

${ }^{*}$ Corresponding author: E-mail address: hafed.elfeki@yahoo.fr

\begin{abstract}
Adenosine triphosphate (ATP) is the main source of energy for cells. In this article we investigated, with a possible future finality in bone tissue engineering, the original association of ATP molecules and hydroxyapatite (HAp) fine powders. We have in particular inspected, in a preliminary way, the effects of the presence of ATP molecules on the physico-chemistry of apatite compounds obtained via co-precipitation. Hybrids were produced by association of increasing amounts of adenosine 5'-triphosphate (ATP) disodium hydrate salt with hydroxyapatite, leading to so-called "organoapatites". The structure and composition of the polycrystalline hybrid compounds obtained were studied by XRD, FTIR, SEM and magic angle spinning (MAS) NMR techniques. The presence of ATP was found to alter the apatite crystallization process, leading to a departure from stoichiometry. MAS-NMR data attest to the presence of strong interactions between functional groups of ATP and apatite particles unveiling the obtainment of class II hybrids with potential future applications in cellloaded bone scaffolds.
\end{abstract}

\section{Indexing terms/Keywords}

Hydroxyapatite; Adenosine triphosphate; Grafting; Biomaterials.

\section{Academic Discipline and Sub-Disciplines}

Inorganic Chemistry

\section{SUBJECT CLASSIFICATION}

Apatite Study

\section{TYPE (METHOD/APPROACH)}

Synthesis and spectroscopy analysis

\section{Council for Innovative Research}

Peer Review Research Publishing System

Journal: Journal of Advances in Chemistry

Vol. 9, No. 1

editorjaconline@gmail.com

www.jac.cirworld.com, member.cirworld.com 


\section{INTRODUCTION}

Hydroxyapatite $\left(\mathrm{Ca}_{10}\left(\mathrm{PO}_{4}\right)_{6}(\mathrm{OH})_{2}\right.$, denoted here "HAp") was used extensively for different medical applications such as bone repair biomaterials due to its excellent biocompatibility with human tissues [1]. HAp crystallizes in the hexagonal system (space group P63/m), typically with cell parameters $a=b=9.432 \AA$ and $c=6.881 \AA$ [2]. The arrangement of phosphate ions in the structure provides two types of channels (types I and II) containing calcium ions in two different environments, namely $\mathrm{Ca}$ (I) and $\mathrm{Ca}$ (II) [3]. Ca (I) crystallographic sites then form ionic columns parallel to the c-axis, with each $\mathrm{Ca}$ (I) ion coordinated to nine oxygen atoms, i.e. three of each from $\mathrm{O}(1), \mathrm{O}(2)$ and $\mathrm{O}(3)$ atoms. Ca (II) ions, in contrast, form equilateral Ca3-triangles, with each $\mathrm{Ca}$ (II) ion coordinated to 7 oxygen atoms, one $\mathrm{O}(1)$, one $\mathrm{O}(2)$, four $\mathrm{O}$ (3) and one oxygen from a hydroxide ion; where hydroxide ions are present on the axis of type II-channels. It may be noted that $\mathrm{Ca}$ (II) sites correspond, in this structure, to larger volumes than $\mathrm{Ca}$ (I) sites.

The properties of synthetic HAp are determined by its chemical composition (nonstoichiometry being rather common), structure, particle morphology and crystallite size which are strongly dependent on preparation methods. Nowadays, a number of protocols have been used for HAp synthesis, such as co-precipitation [4], hydrothermal reaction [5], sol-gel synthesis [6], microemulsion synthesis [7], mechanochemical synthesis [8], combustion synthesis [9] and sonochemical synthesis [10].

Several works were also carried out on the preparation of organic-mineral hybrid apatite-based systems to show the influence of adsorbed organic molecules or surface functionalizations on structural and thermal properties, showing that organic species are among the most effective crystal growth inhibitors for calcium phosphates [11].

Recently, in order to inspect the type of interaction existing between HAp crystals and living cells, investigations have been undergone to study the surface reactivity of HAp-based nanomaterials exposing different organic functions [12-13].

On the other hand, molecules exposing phosphonate groups have important implications/applications both in biomineralization processes and for the biomaterials industry [14]. The high reactivity of apatites with organic phosphoruscontaining molecules resides in the presence of charges (calcium and phosphate surface ions) and potentially also of amphoteric sites on their surface [15]. These surface ions/sites may then enable interactions with organic additives to form hybrid apatite-based materials [16], while the organic moieties can change the surface chemical properties of the solid (hydrophilicity, reactivity), as well as structural and physical properties. The presence of grafted (bio)molecules can open many perspectives in the development of applications, especially in the field of bone tissue engineering (a review is accessible on ref. [17])

Adenosine 5'-triphosphate (ATP) is the most common energy carrier for cells [18]. It is a nucleotide constituted of adenosine (association of adenine and ribose) and of three phosphate groups linked together in a linear arrangement (the PO4 groups are denoted " $\alpha$ ", " $\beta$ " and " $\gamma$ ", alpha being the closest to the ribose). How extracellular ATP may interact with cells and living tissues is still a matter of concern and of questions, whether for cancerous or non-cancerous sites.

Recently, nucleic acid and nucleotide-mediated synthesis of inorganic nanoparticles (not of apatitic nature) was reported [19]. For apatitic systems, association with ATP may find future applications in the field of tissue engineering (and/or allow one to better understand cellular activity around bone cancer sites), with the goal to potentially modify advantageously the local cellular activity by providing "additional" ATP in the vicinity of cells. The objective of the present contribution, dedicated to preliminary physico-chemical investigations on this topic, is to demonstrate the possibility to prepared hybrids associating ATP molecules (in the form of their sodium salt $\mathrm{Na}_{2} \mathrm{ATP}$ ) and hydroxyapatite, via a rapid and easy precipitation method; and to inspect the effects of different $\mathrm{Na}_{2} \mathrm{ATP}$ contents on physico-chemical characteristics of the hybrids.

\section{EXPERIMENTAL}

\subsection{Material preparation}

HAp was prepared by a wet chemical method previously reported [20]. Briefly, 1.67 mol of $\mathrm{Ca}\left(\mathrm{NO}_{3}\right)_{2}, 4 \mathrm{H}_{2} \mathrm{O}$ and 1 mol of (NH4)2HPO4, corresponding to the HAp stoichiometric molar ratio of $\mathrm{Ca} / \mathrm{P}=1.67$, were independently dissolved in distilled water at room temperature. The phosphate-containing solution was quickly added to the calcium solution using 10 $\mathrm{ml}$ of concentrated ammonia solution at $\mathrm{pH}=8$ and the mixture was stirred for $1 \mathrm{~h}$ at $25^{\circ} \mathrm{C}$. The final gel was aged for $24 \mathrm{~h}$ at $80^{\circ} \mathrm{C}$ and left to mature for a total of 16 hours. It was then filtered and thoroughly washed with distilled water. The recovered precipitate was dried overnight at $80^{\circ} \mathrm{C}$.

So-called "organoapatites", associating HAp and adenosine 5'-triphosphate disodium hydrate salt ( $\left.\mathrm{Na}_{2} \mathrm{ATP}\right)$ and denoted "Hap - $\mathrm{xNa}_{2} \mathrm{ATP}$ ", were prepared by a modified protocol, using a mixture of $(1-\mathrm{x} / 3) \mathrm{mol}$ of $(\mathrm{NH} 4)_{2} \mathrm{HPO}_{4}$ and $\mathrm{x} / 3 \mathrm{~mol}$ of $\mathrm{Na}_{2}$ ATP with $\mathrm{x}=2.5 \%, 5 \%, 10 \%$ was first dissolved in a $100 \mathrm{ml}$ volume of an acetone-water mixture $(50: 50 \%$, v/v) at $25^{\circ} \mathrm{C}$,during this process, the $\mathrm{pH}$ value was maintained at 7.4 by slow addition of $1 \mathrm{M} \mathrm{NH}_{4} \mathrm{OH}$. The mixture was stirred in water for $30 \mathrm{~min}$ at room temperature. The "phosphate" solution (containing both inorganic phosphate ions "Pi" and phosphate groups from the ATP molecules) was added rapidly to the calcium solution, then stirred for $1 \mathrm{~h}$ and the suspension was homogenized by ultrasonic and mechanical agitation for $24 \mathrm{~h}$ at $37^{\circ} \mathrm{C}$. The gel was decanted, matured during $16 \mathrm{~h}$ at $80^{\circ} \mathrm{C}$ and dried at $80^{\circ} \mathrm{C}$ in a conventional oven under air atmosphere . Calcination at $900{ }^{\circ} \mathrm{C}$ in air was also carried out when appropriate (see text). Table .1 summarizes the starting synthesis conditions. 
Table1. Starting synthesis conditions for the preparation of ATP-HAp organoapatites.

\begin{tabular}{|c|c|c|c|c|c|c|c|c|}
\hline \multirow[t]{2}{*}{$\mathrm{HAp}-\mathrm{x} \% \mathrm{Na}_{2} \mathrm{ATP}$} & \multicolumn{2}{|c|}{$\mathrm{Ca}\left(\mathrm{NO}_{3}\right)_{2}, 4 \mathrm{H}_{2} \mathrm{O}$} & \multicolumn{3}{|c|}{$\begin{array}{c}\left(\mathrm{NH}_{4}\right)_{2} \mathrm{HPO}_{4} \\
\text { (=inorganic phosphate, } \mathrm{Pi})\end{array}$} & \multicolumn{2}{|c|}{$\mathrm{Na}_{2}$ ATP. $3 \mathrm{H}_{2} \mathrm{O}$} & \multirow[t]{2}{*}{$\mathrm{Ca} / \mathrm{P}$} \\
\hline & Mole & g & Mole & & $g$ & Mole & & \\
\hline Hap & \multirow{4}{*}{0.1667} & \multirow{4}{*}{39.35} & 0,100 & 13.2 & & 0 & 0 & \multirow{4}{*}{1.667} \\
\hline HAp-2.5\% $\mathrm{Na}_{2} \mathrm{ATP}$ & & & 0.0975 & 12.87 & & $2.5 * 1 / 3.10-3$ & 0.50 & \\
\hline HAp-5\%Na 2 ATP & & & 0,095 & 12.54 & & $5^{\star} 1 / 3.10-3$ & 1 & \\
\hline HAp-10\%Na 2 ATP & & & 0,090 & 11.88 & & $10 * 1 / 3.10-3$ & 2.01 & \\
\hline
\end{tabular}

\subsection{Physico-chemical characterization}

The powder samples were subjected to XRD (after calcination at $900^{\circ} \mathrm{C}$ in air), and to multinuclear solid state MAS-NMR spectroscopy, FTIR measurements and scanning electron microscopy (SEM) observations:

XRD patterns were recorded using a diffractometer Philips PW 3710 in the $2 \Theta$ range $5-60^{\circ}$ using CuKa1 $(\lambda=1.54051 \AA)$ radiation.

Morphology and particle dimensions/agglomeration state of HAp modified by different amounts of $\mathrm{Na}_{2} \mathrm{ATP}$ were followed using a scanning electron microscope (JSM-6301, JEOL Inc.) at a voltage of $25 \mathrm{kV}$ and a current of $100 \mathrm{~mA}$. Solid-state ${ }^{1} \mathrm{H}$ and ${ }^{31} \mathrm{P}$ NMR spectra were recorded using MAS mode.

An NMR BRUKER $300 \mathrm{MHz}$ (7.1T) spectrometer was used, with cross polarization (CP) and magic-angle spinning (MAS) at $63.633 \mathrm{MHz}$ (proton and phosphorus Larmor frequencies of 399.5 and $161.7 \mathrm{MHz}$, respectively). The MAS rotation rate corresponded to $7 \mathrm{kHz}$. The chemical shift for phosphorus is reported with respect to a $85 \%$ solution of phosphoric acid (H3PO4) as external standard; and tetramethylsilane (TMS) was used as standard for ${ }^{1} \mathrm{H}$ NMR. High-power proton decoupling technique was applied during the recording of ${ }^{31} \mathrm{P}$ NMR spectra.

FTIR (JASCO FT-IR 420) was used to study the vibrational features of the compounds. $1 \mathrm{mg}$ of dried sample powder was compacted with $0.1-0.15 \mathrm{~g}$ potassium bromide using a hydraulic pressure. For each spectrum, 32 scans between 400 and $4000 \mathrm{~cm} 1$ were recorded.

\section{RESULTS AND DISCUSSION}

\subsection{XRD diffraction}

Typical XRD profiles of HAp ceramics (calcined at $900^{\circ} \mathrm{C}$ in air) synthesized here and of crystalline apatite hybrids with ATP (HAp- $\% \% \mathrm{Na}_{2}$ ATP) are shown in Fig. 1. The diffraction pattern relating to "pure" HAp confirms the apatitic nature of this compound. This phase crystallizes in the hexagonal system (space group: $P 63 / \mathrm{m}$ ) with the following unit cell parameters: $\mathrm{a}=9.426(3) \AA ; \mathrm{c}=6.883(5) \AA$. In the presence of ATP in the precipitation medium however, the calcination at $900^{\circ} \mathrm{C}$ allowed the partial conversion of the apatite phase contained in hybrids HAp $-5 \% \mathrm{Na}_{2} \mathrm{ATP}$ and $\mathrm{HAp}-10 \% \mathrm{Na} 2 \mathrm{ATP}$ particles into $\beta$-tricalcium phosphate $\mathrm{Ca}_{3}\left(\mathrm{PO}_{4}\right)_{2}(\beta$-TCP). In particular, the diffraction peaks of $\beta$-tricalcium phosphate appear at 2theta values of $27.78,30.61$ and $33.76^{\circ}$. Interestingly, the extent of this conversion is found to increase with the associated $\mathrm{Na}_{2} \mathrm{ATP}$ content. Such Hap/ $\beta$-TCP mixtures are generally obtained when calcining nonstoichiometric apatites, i.e. corresponding to $\mathrm{Ca} / \mathrm{P}$ ratios lower than 1.67 . These findings thus suggest that, for increasing $\mathrm{Na}{ }_{2} \mathrm{ATP}$ amounts in the precipitating mixture, the apatite phase obtained increasingly departs from stoichiometry. These findings can most probably be related to an inhibitory effect of ATP molecules on the apatite crystal growth process. 


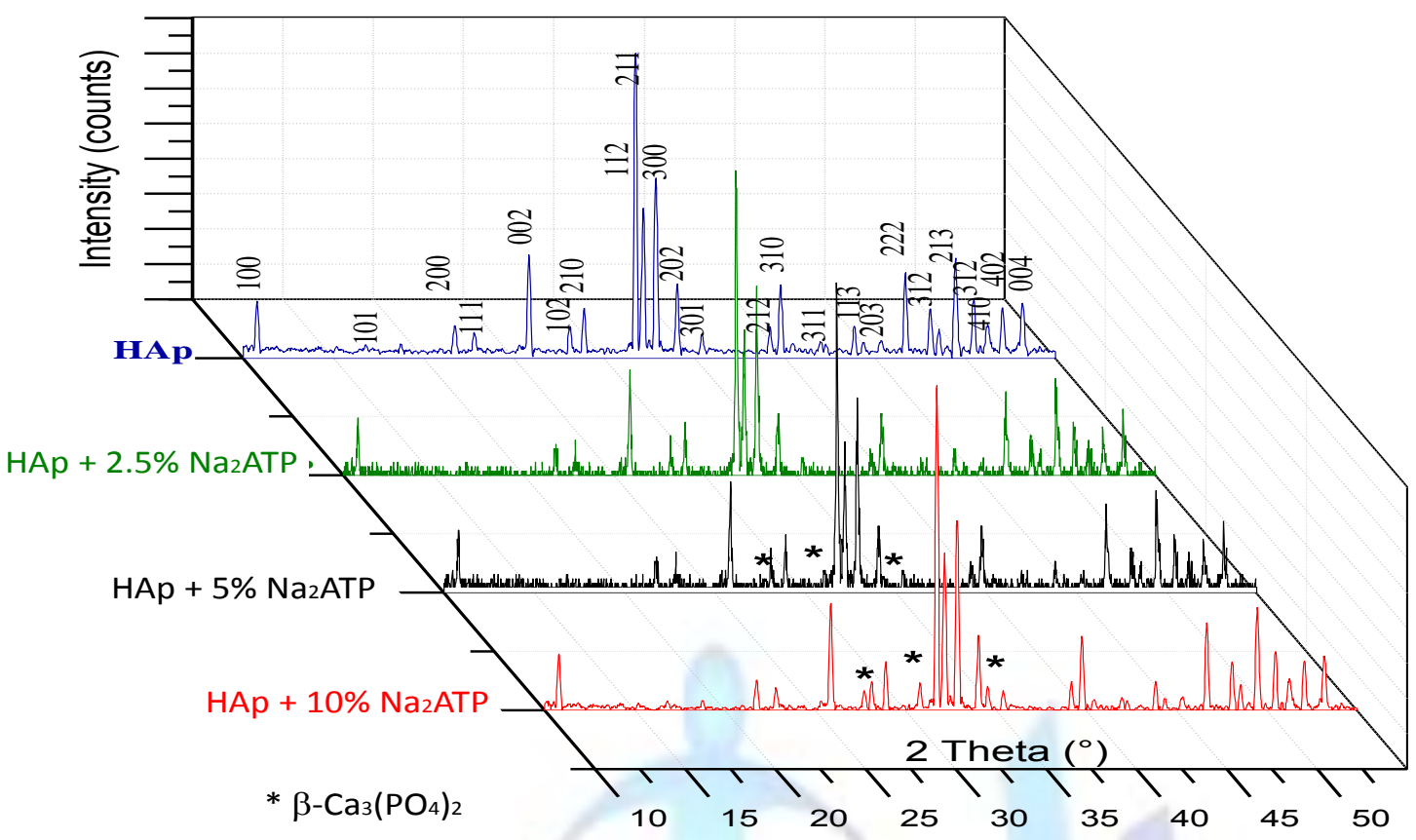

Fig 1: X-ray diffraction pattern for $\mathrm{HAp}-\mathrm{x} \% \mathrm{Na}_{2} \mathrm{ATP}$ synthesized by co-precipitation (after calcination at $900^{\circ} \mathrm{C}$ ).

\section{2. ${ }^{31}$ P-MAS NMR spectroscopy investigation}

In order to obtain further information on the bonding of ATP molecules onto hydroxyapatite, ${ }^{31} \mathrm{P}$ and ${ }^{1} \mathrm{H}$ MAS-NMR measurements were performed. In a first stage, ${ }^{31} \mathrm{P}$ MAS-NMR analyses (on samples dried at $80^{\circ} \mathrm{C}$ ) were carried out (Fig. 2). As expected for a hydroxyapatite phase, the ${ }^{31} \mathrm{P}$ NMR signal for pure HAp gave rise (see Figs. 2a,2b) to a single phosphorus peak around $2.8 \mathrm{ppm}$ relative to $85 \% \mathrm{H}_{3} \mathrm{PO}_{4}$ (experimental value: $2.83 \mathrm{ppm}$ ), similar to the phosphorus peak found in other synthetic apatites as well as in bone and teeth [21-22]. It relates to the position of apatitic phosphorus signal as reported in previous works [23-24]. It may be noted that, in this study, no protonated phosphate (e.g. $\mathrm{HPO}_{4}{ }^{2-}$ ions giving rise to an additional contribution typically around 1.4 [25]) has been clearly detected in any sample. In contrast, in addition to this main peak, the ${ }^{31} \mathrm{P}$ NMR data obtained for the HAp- $\mathrm{x} \% \mathrm{Na}_{2} \mathrm{ATP}$ hybrids pointed out the presence of secondary signals in the form of broad resonances clearly detectable at $-7.16 \mathrm{ppm}$ and $-21.3 \mathrm{ppm}$ (see Fig. 2c). These positions remind those observed for ${ }^{31} \mathrm{P}$ in pure $\mathrm{Na}_{2}$ ATP (see Fig. 2d), respectively at -7.76 (phosphate " $\mathrm{Y}$ ") and -19.63 ppm (phosphate " $\beta$ "). The slight but detectable variation in chemical shifts of these two peaks is also interesting to remark, as this can be interpreted as the formation of HAp- $\mathrm{Na}_{2} \mathrm{ATP}$ complexes (indicative of strong interactions between HAp crystals and $\mathrm{Na}_{2} \mathrm{ATP}$ molecules) rather than a simple mechanical mixture between non-interacting entities [26]. These findings are also corroborated by the detection of a slight shift of the apatitic ${ }^{31} \mathrm{P}$ NMR signal from 2.83 down to about 2.76 ppm (Fig. $2 \mathrm{~b}$ and Table 2) for $\mathrm{Na}_{2}$ ATP contents between 0 and $10 \%$. 


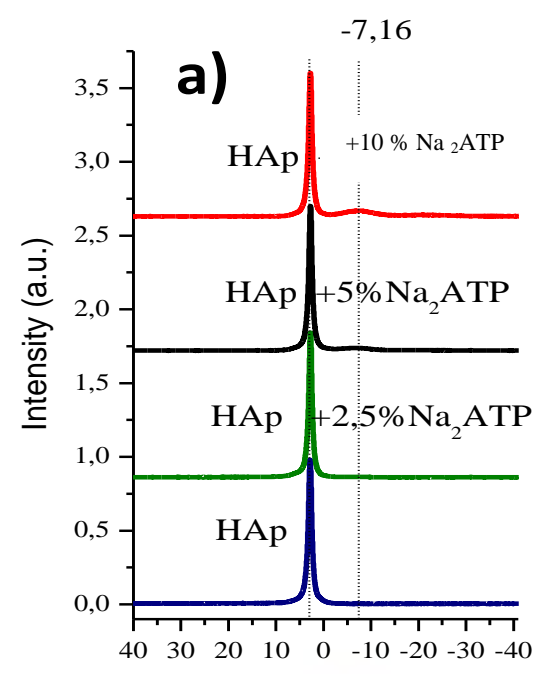

${ }^{31} \mathrm{P}$ chemical shift, ppm
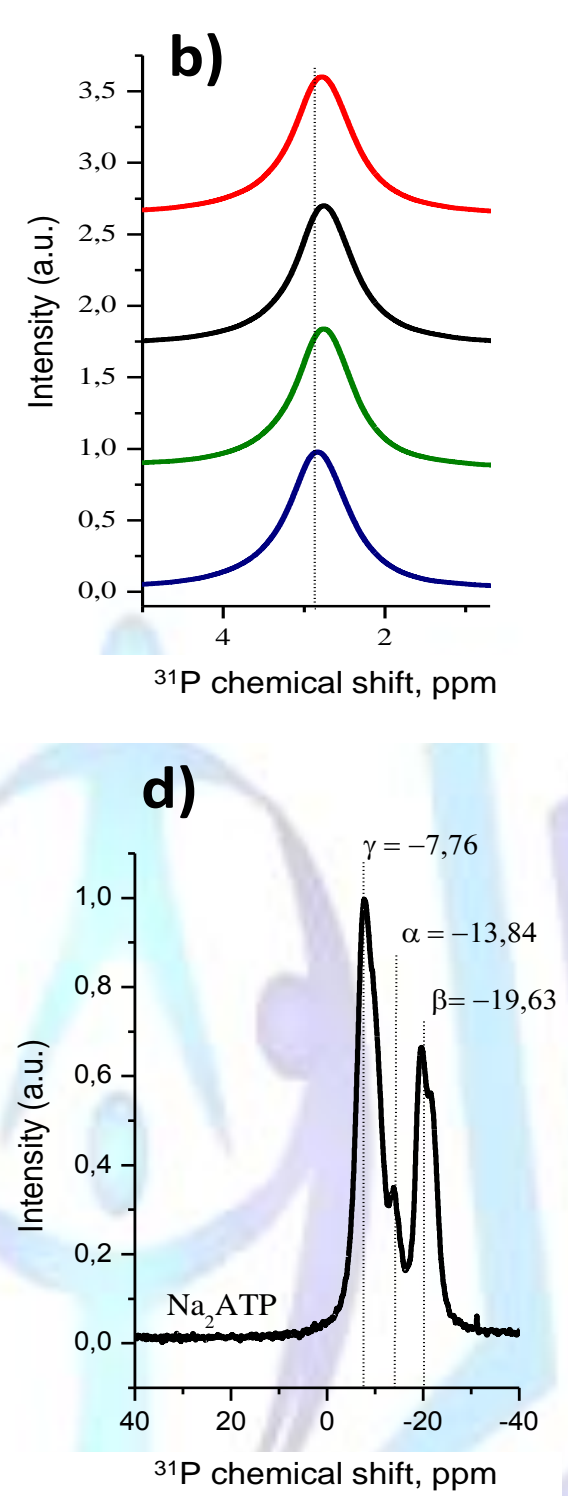

Fig 2: ${ }^{31} \mathrm{P}$ NMR spectra of the organoapatite (Hap- $\mathrm{x} \% \mathrm{Na}_{2} \mathrm{ATP}$ ) (dried at $80{ }^{\circ} \mathrm{C}$ ): a) full spectra, b) main ${ }^{31} \mathrm{P}$ peak, $\mathrm{C}$ ) zoom on basis of main peak, d) spectrum for pure $\mathrm{Na}_{2} \mathrm{ATP}$.

Such ${ }^{31} \mathrm{P}$ NMR data thus point out strong interactions occurring at the interface apatite-ATP. They attest to a change in the local environment of the ${ }^{31} \mathrm{P}$ nuclei, which may be related to the discussion of Vasavada et al [27] on the interaction of calcium ions with nucleotides. An interaction is indeed likely to take place between surface calcium ions from apatite particles and phosphate groups of the ATP molecules. Phosphate-coordinated metal ions (e.g. Ca2+ in our case) may also bind to the N-7 nitrogen in the purine residue (innersphere-type of complex, Fig. 3a), or interact with N-7 via a water molecule forming an outersphere-type of complex (Fig. 3b). Such calcium ions-ATP interactions probably play a role in the formation of Ca2+-ATP soluble complexes during the precipitation process, and possibly also directly until the grafting of ATP molecules on the apatite surface. It is worth noting here also that no trace of secondary phase has been detected in this study on such apatite-ATP hybrids, therefore suggesting that the ATP molecules are interacting directly with the apatite surface (rather than a scenario where some insoluble calcium ATP slat would form and co-precipitate beside apatite). 


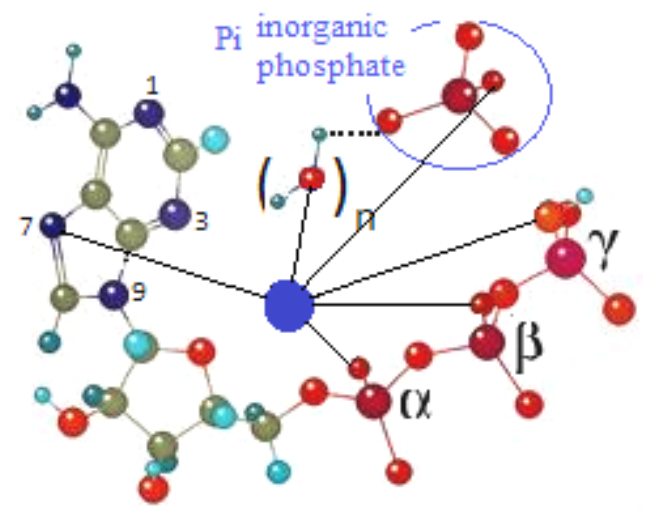

a )

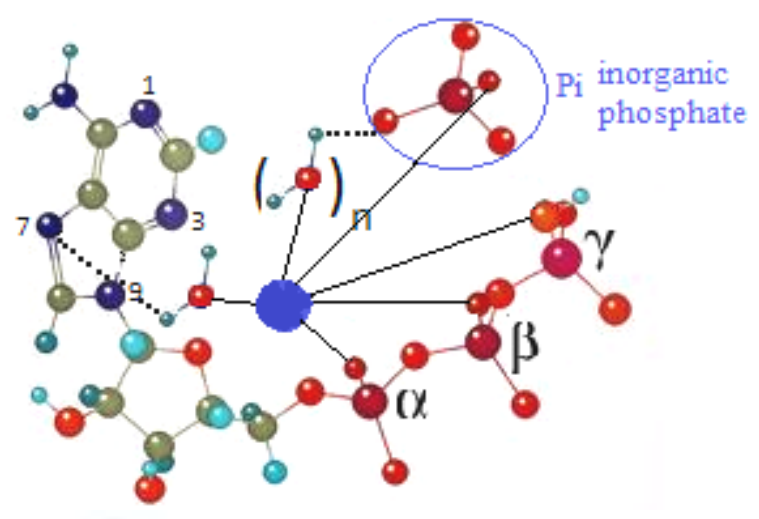

b)

Fig 3: Structures for chelated ATP complexes formed by inner- (a) and outer-sphere (b) coordination of the purine residue (the central ion "॰" denotes a calcium ion.

\section{3. ${ }^{1} \mathrm{H}$-MAS NMR spectroscopy investigation}

In order to probe hydrogen environments in such organoapatite hybrids, ${ }^{1} \mathrm{H}$ MAS NMR data were recorded. The results have been added in Table 2. Fig. 4 reports the ${ }^{1} \mathrm{H}$ NMR spectra obtained, pointing out two intense broad peaks centered on -0.05 and $6.81 \mathrm{ppm}$, respectively.

The NMR peak near -0.05 ppm can be assigned to apatitic $\mathrm{OH}^{-}$ions from the Hap phase [28]; and the peak observed around $6.81 \mathrm{ppm}$ may presumably be assigned to surface-adsorbed water on apatite crystals, as was previously found for hydroxyapatite ceramics with colloidal-like dimensions [29].

It is clear from Table 2 that the chemical shifts and line widths (FWHM) of the proton NMR spectra vary as we compare the profiles for different amounts of $\mathrm{Na}_{2}$ ATP. The line widths (FWHM) for apatitic $\mathrm{OH}$ - ions increase from $0.77 \mathrm{ppm}$ (for pure $\mathrm{HAp}$ ) to $0.96,0.93$ and $0.92 \mathrm{ppm}$ for the $2.5 \%, 5 \%$ and $10 \% \mathrm{Na}_{2} \mathrm{ATP}-\mathrm{Hap}$ hybrids respectively. As for phosphorus, such spectral modifications upon ATP association suggest the existence of strong interactions between the organic molecules and the apatite surface like in "class II" hybrids [30] (which are defined as hybrids involving strong binding between an organic entity and an inorganic substrate, as opposed to class I hybrids which exhibit only a weak interaction). In the present case, this situation may be related to the binding of some functional groups from the ATP molecules and some accessible calcium sites from the apatite surface. As mentioned previously, $\mathrm{Ca}^{2+}$ ions are likely to interact with phosphate groups from ATP and may present also some affinity for the aromatic site of nucleobase residues. In any case, the interaction of phosphate groups and calcium ions from the surface of apatite particles probably determines a large part of the stability of such hybrids [31].

The intensity of the ${ }^{1} \mathrm{H}$ band related to apatitic $\mathrm{OH}^{-}$is also found to decrease when the ATP content increases (Fig. 3). This is in agreement with our above findings (see Fig. 1 and related text) pointing out a greater departure from stoichiometry for apatite phases precipitated in the presence of ATP molecules. In this context, the configuration of $\mathrm{Na}_{2}$ ATP molecules and the orientation of the nitrogen may play a role in mineral binding affinity [32]. These complex processes appear to slow down the restructuration of immature apatite crystals towards more stable states, possibly by blocking "active" growth sites of the apatite phase. 
Table 2. ${ }^{1} \mathrm{H}$ and ${ }^{31} \mathrm{P}$ chemical shifts and MAS line widths of HAp functionalized with $\mathrm{Na}_{2} \mathrm{ATP}$ at various percent.

\begin{tabular}{|c|c|c|c|c|c|c|}
\hline \multirow[b]{2}{*}{$\begin{array}{l}\text { Sample (dried at } \\
\left.80^{\circ} \mathrm{C}\right)\end{array}$} & \multicolumn{3}{|c|}{${ }^{1} \mathrm{H}$ MAS NMR } & \multicolumn{3}{|c|}{${ }^{31} \mathrm{P}$ MAS NMR } \\
\hline & Assignment & $\begin{array}{l}\text { Chemical } \\
\text { shift (ppm) }\end{array}$ & $\begin{array}{l}\text { line width } \\
\text { (ppm) }\end{array}$ & Assignment & $\begin{array}{r}\text { Chemical } \\
\text { shift (ppm) }\end{array}$ & $\begin{array}{l}\text { line width } \\
\text { (ppm) }\end{array}$ \\
\hline \multirow[b]{2}{*}{ HAp } & $\mathrm{OH}-$ & -0.05 & 0.77 & \multirow[b]{2}{*}{$\mathrm{PO}_{4}{ }^{3-}$} & \multirow[b]{2}{*}{2.83} & \multirow[b]{2}{*}{0.90} \\
\hline & Surface $\mathrm{H}_{2} \mathrm{O}$ & 6.81 & 2.18 & & & \\
\hline \multirow[t]{2}{*}{ HAp-2.5\% $\mathrm{Na}_{2}$ ATP } & $\mathrm{OH}-$ & -0.24 & 0.96 & \multirow[b]{2}{*}{$\mathrm{PO}_{4}{ }^{3-}$} & \multirow[b]{2}{*}{2.77} & \multirow[b]{2}{*}{0.91} \\
\hline & Surface $\mathrm{H}_{2} \mathrm{O}$ & 6.34 & 3.33 & & & \\
\hline \multirow[t]{2}{*}{ HAp-5\%Na ${ }_{2}$ ATP } & $\mathrm{OH}-$ & -0.20 & 0.93 & \multirow[b]{2}{*}{$\mathrm{PO}_{4}{ }^{3-}$} & \multirow[b]{2}{*}{2.77} & \multirow[b]{2}{*}{0.91} \\
\hline & Surface $\mathrm{H}_{2} \mathrm{O}$ & 6.65 & 2 & & & \\
\hline \multirow[t]{2}{*}{ HAp-10\%Na 2 ATP } & $\mathrm{OH}-$ & -0.20 & 0.92 & \multirow[b]{2}{*}{$\mathrm{PO}_{4}^{3-}$} & \multirow[b]{2}{*}{2.76} & \multirow[b]{2}{*}{0.91} \\
\hline & Surface $\mathrm{H}_{2} \mathrm{O}$ & 6.65 & 1.3 & & & \\
\hline
\end{tabular}

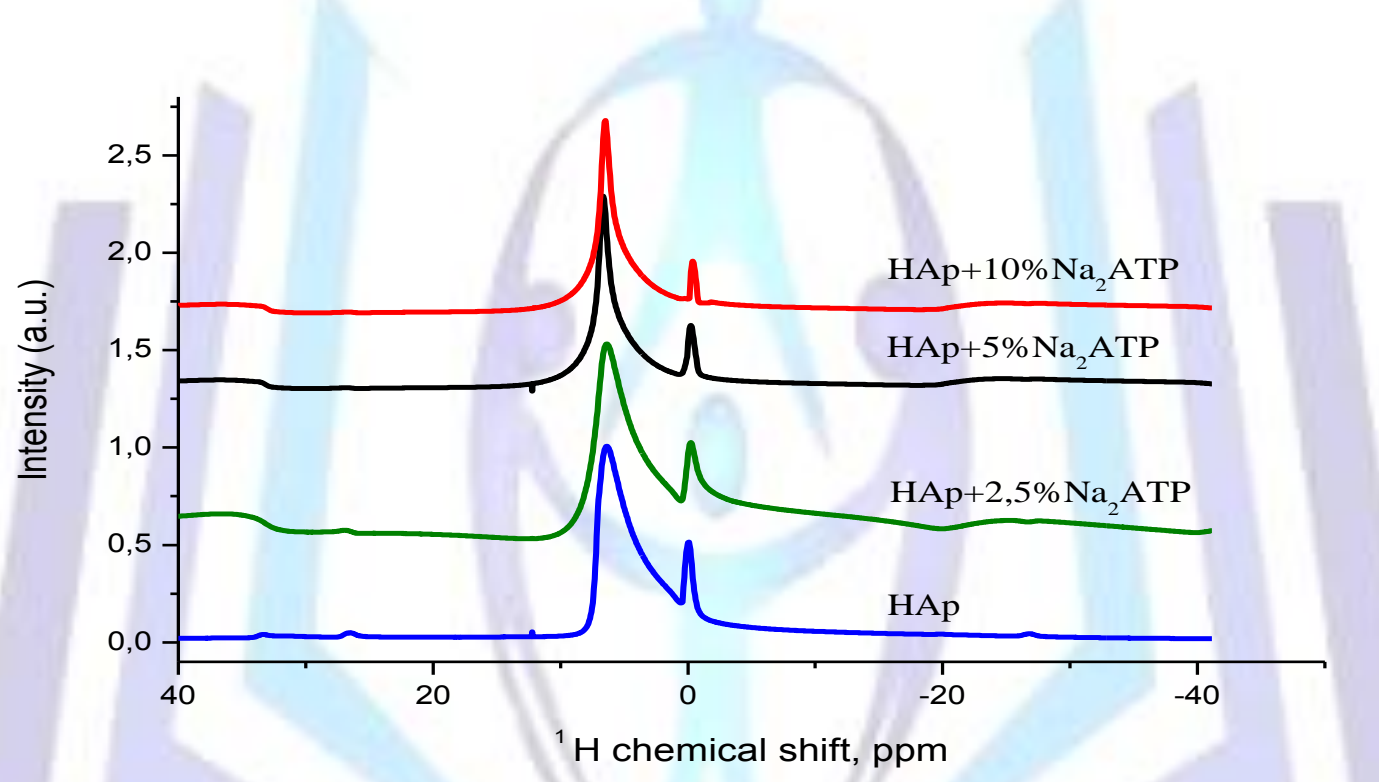

Fig 4: ${ }^{1} \mathrm{H}$ NMR spectra of the organoapatite (HAp- $\left.\mathrm{x} \% \mathrm{Na}_{2} \mathrm{ATP}\right)\left(\mathrm{dried}\right.$ at $\left.80^{\circ} \mathrm{C}\right)$.

\subsection{Infrared spectroscopy investigation and Scanning Electron Microscopy (SEM)}

Fig.5. shows the FTIR spectra of the various hybrids (heated at $80^{\circ} \mathrm{C}$ ). The infrared band positions and their assignments are summarized in Table 3. These data confirm in particular the presence of ATP molecules associated to the apatite phase: broad bands appear in particular at 717 and $912 \mathrm{~cm}-1$, characteristic of ATP. These two bands are assignable respectively to asymmetric and symmetric stretching vibration of the P-O-P bridge. The band at $912 \mathrm{~cm}-1 \mathrm{may}$ for instance be attributed to the $\mathrm{P}_{\beta}-\mathrm{O}-\mathrm{P}_{\mathrm{y}}$ vibration in ATP. For the ATP-apatite hybrids, additional peaks related to P-O-P from adenine-nucleotides species are also detectable at $1244 \mathrm{~cm} \_1$, which is characteristically generated by the $v_{\text {as }} \mathrm{PO}^{2-}$ vibration in ATP [33-34-35].

Characteristic frequencies assigned to $\mathrm{PO}_{4}$ groups in HAp occur at $1096 \mathrm{~cm}-1,1040 \mathrm{~cm}-1,963 \mathrm{~cm}-1$ and at $603 \mathrm{~cm}-1$, $568 \mathrm{~cm}-1$ as discussed in previous publications [36-37]. A broad band attributed to water O-H stretching vibrations appears at $3500 \mathrm{~cm}-1$ for all samples. It is also associated to the deformation band of water molecules that appears around $1640 \mathrm{~cm}-1$. These observations point out the high hydration state of such polycrystalline apatites. Weaker bands attributable to apatitic $\mathrm{OH}$ - ions are also visible around 3570 and $632 \mathrm{~cm}-1$. The decrease in intensity of these two contributions as the amount of ATP increases is in perfect agreement with our previous findings indicating the departure from stoichiometry of apatite in these conditions. 
Table3. Assignments of the observed vibrational frequencies of $\mathrm{HAp}-\mathrm{x} \% \mathrm{Na}_{2} \mathrm{ATP}$ hybrids (dried at $80^{\circ} \mathrm{C}$ ).

\begin{tabular}{|c|c|c|c|c|c|c|c|c|}
\hline \multirow[t]{2}{*}{ Assignments } & \multicolumn{8}{|c|}{ Observed vibrational frequencies $(\mathrm{cm}-1)$} \\
\hline & $\begin{array}{l}\text { HAp } \\
\text { position }\end{array}$ & intensity & $\begin{array}{l}2.5 \% \mathrm{Na}_{2} \\
\text { position }\end{array}$ & $\begin{array}{l}\text { TP-HAp } \\
\text { intensity }\end{array}$ & $\begin{array}{l}5 \% \mathrm{Na}_{2} \mathrm{~A} \\
\text { position }\end{array}$ & $\begin{array}{l}\mathrm{P}-\mathrm{HAp} \\
\text { intensity }\end{array}$ & $\begin{array}{l}10 \% \mathrm{Na}_{2} \mathrm{f} \\
\text { position }\end{array}$ & $\begin{array}{l}\text { TP-HAp } \\
\text { intensity }\end{array}$ \\
\hline $\mathrm{PO}_{4}$ bend $\mathrm{v}_{2}$ & 475 & low & 475 & low & 474 & low & 473 & low \\
\hline $\mathrm{PO}_{4}$ bend $v_{4}$ & 568 & strong & 568 & strong & 568 & strong & 568 & strong \\
\hline $\mathrm{PO}_{4}$ bend $v_{4}$ & 605 & strong & 602 & strong & 602 & strong & 602 & strong \\
\hline Structural $\mathrm{OH}$ & 635 & low & 632 & low & 631 & low & 632 & very low \\
\hline P-Ô-P bend $v_{s}$ & & - & 717 & very low & 717 & low & 717 & average \\
\hline P-Ô-P bend $v_{\text {as }}$ & & - & 912 & low & 912 & low & 912 & average \\
\hline $\mathrm{PO}_{4}$ stretch $v_{1}$ & 963 & average & 962 & average & 962 & average & 961 & average \\
\hline $\mathrm{PO}_{4}$ bend $v_{3}$ & 1040 & strong & 1038 & strong & 1038 & strong & 1037 & strong \\
\hline $\mathrm{PO}_{4}$ bend $v_{3}$ & 1096 & average & 1094 & average & 1093 & average & 1092 & average \\
\hline $\mathrm{H}_{2} \mathrm{O}$ adsorbed $\left(v_{2}\right)$ & 1647 & average & 1642 & average & 1642 & average & 1641 & average \\
\hline $\mathrm{H}_{2} \mathrm{O}$ adsorbed & 3427 & average & 3425 & average & 3425 & average & 3439 & average \\
\hline apatitic $\mathrm{OH}-$ & 3571 & low & 3571 & low & 3570 & low & 3569 & very low \\
\hline
\end{tabular}
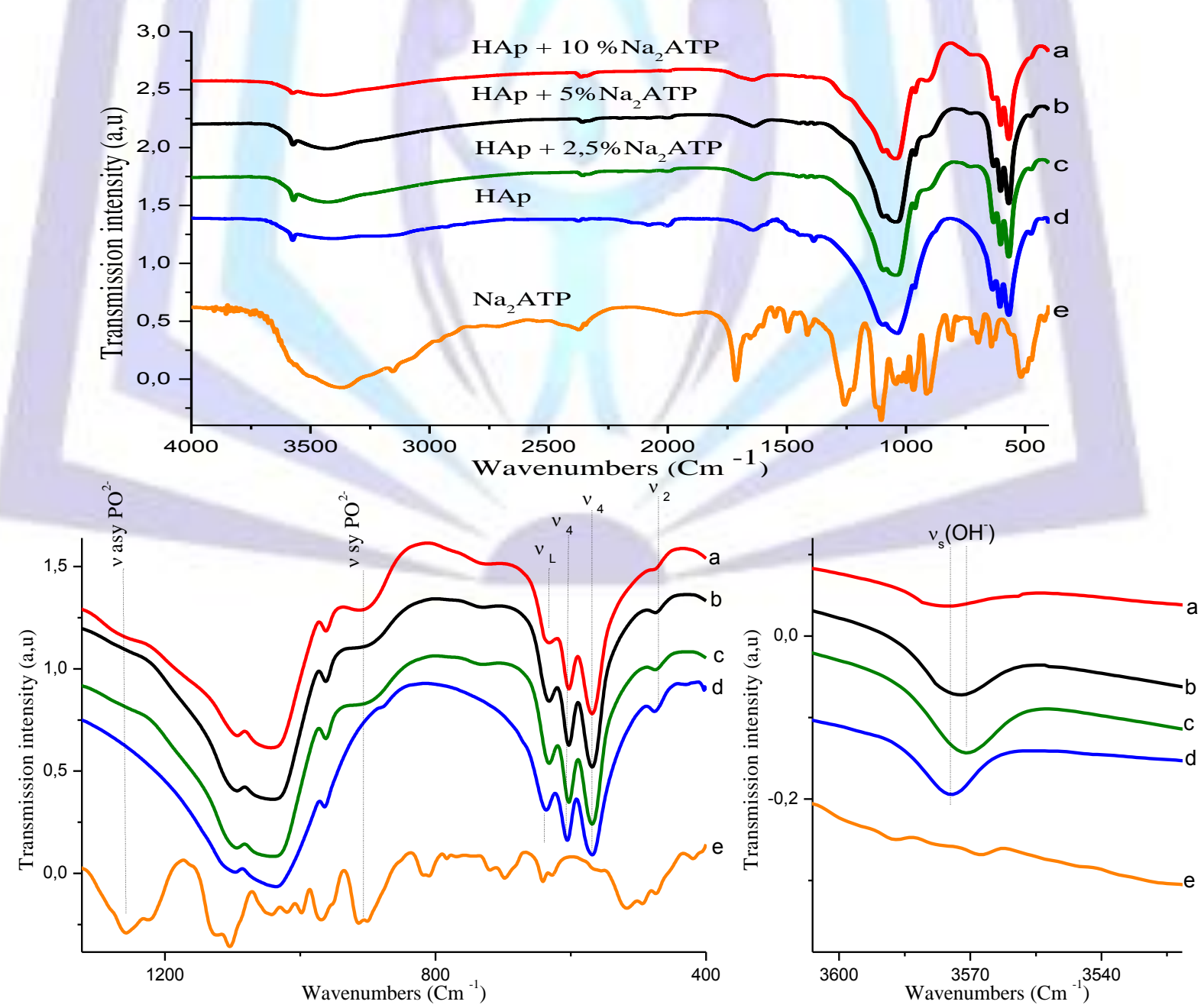

Fig 5: Infrared spectra of HAp - x\%Na2ATP with different Na2ATP contents. 
SEM analyses (Fig. 6) indicated that the materials consist of aggregated particles. Interestingly, with $2.5 \%$ and $5 \%$ of $\mathrm{Na}_{2} \mathrm{ATP}$, one can observe a rather open structure with individual particles easy to distinguish, whereas the density of aggregation appears to increase at $10 \% \mathrm{Na}_{2}$ ATP. This fact points out some effect on apatite particle aggregation played by adsorbed ATP molecules, thus likely to modify electrostatic interparticle interactions.

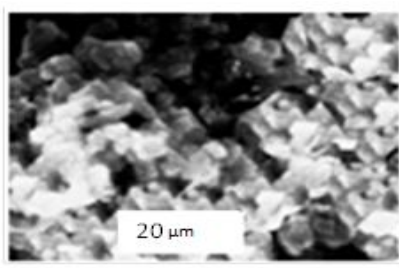

HAp

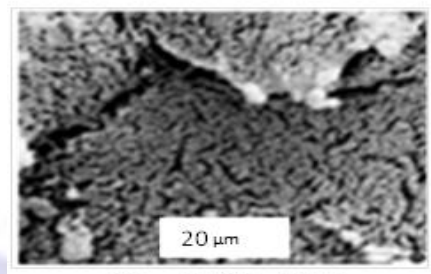

HAp $-5 \% \mathrm{Na}_{2} \mathrm{ATP}$

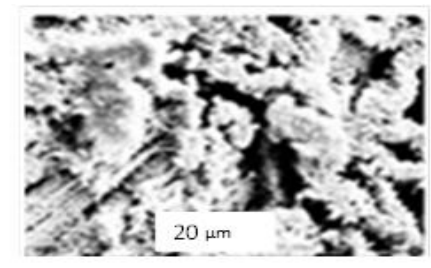

HAp-2.5\% $\mathrm{Na}_{2} \mathrm{ATP}$

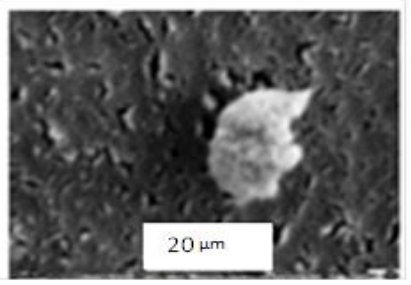

HAP- $10 \% \mathrm{Na}_{2} \mathrm{ATP}$

Fig 6: SEM images of HAp (samples dried at $80^{\circ} \mathrm{C}$ ), (scale bar $=20 \mu \mathrm{m}$ ) and $\mathrm{Hap}-2.5 \% \mathrm{Na}_{2} \mathrm{ATP}, \mathrm{Hap}^{-5} \% \mathrm{Na}_{2} \mathrm{ATP}$, Hap-10\% $\mathrm{Na}_{2} \mathrm{ATP}($ scale bar $=20 \mu \mathrm{m})\left(\right.$ dried at $\left.80^{\circ} \mathrm{C}\right)$.

\section{Concluding remarks}

Apatite precipitation carried out in the presence of ATP molecules (in the form of $\mathrm{Na}_{2}$ ATP hydrate salt) was investigated in this work. The obtainment of class II hybrids, closely associating the organic and inorganic subparts, was evidenced by way of various complementary analyses, especially solid state NMR. The effects of the presence of ATP-grafted molecules on the physico-chemical characteristics of the apatite phase were also investigated. In particular, a departure from stoichiometry was evidenced as the ATP content increased in the precipitating medium, which suggests a role of crystal growth inhibition played by ATP.

This study adds to the existing literature on calcium phosphate apatite-based hybrids and shows the possibility to associate closely ATP molecules and apatite surfaces which may find, in the future, some biomedical applications such as in tissue engineering, by directly exploiting the presence of ATP which represents a source of energy for cells.

\section{REFERENCES}

[1] Oguchi, H., Ishikawa, K., Mizoue, K. et al.1995. Long-term histological evaluation of hydroxyapatite cerammics in humans. Biomaterials, 16 (1995) 33-38

[2] M. I. Kay, R. A. Young and A. S. Posner.1964.Crystal Structure of Hydroxyapatite.Nature, 204 (1964)1050-1052.

[3] H. E. Feki., J. M. Savariault., A. B. Salah.1999. structure refinements by the Rietveld method of partially substituted Hydroxyapatite. J . Alloy Compd, 287 (1999) 114-120.

[4] Bernard, L., Freche, M., Lacout, J. L., and al, Powder Technology. 103 (1999 )19-25.

[5] LIU H.S., Chin T.S., LAI L.S.,et al. 1997.Hydroxyapatite synthesized by a simplified hydrothermal method .J. Ceramic international, 23 (1997) 19-25.

[6] LIU Dean-Mo, Troczynski T., Tseng J.W. 2001. Water-based sol-gel synthesis of hydroxyapatite : proces development .J. Biomaterials, 22 (2001) 1721-1730.

[7] Lim G.K., WANG J.,Ng S.C., et al.1997. Processing of hydroxyapatite via microémulsion and émulsion routes .J . Biomaterials, 18 (1997) 1433-1439.

[8] Yeong K.C.B., WANG J., Ng S.C. 2001 . Mechanochemical synthesis of nanocrystalline hydroxyapatite from CaO and CaHPO4. J . Biomaterials, 22(2001) 2705-2712.

[9] HAN Y. C , LI S .P., WAG X.Y., et al.2004. Synthesis and sintering of nanocrystalline hydroxyapatite powder by citric acid sol-gel combustion method .J. Materials Research Bulletin 39 (2004) 25-32 . 
[10] Kim Wantae , Saito Fumio.2001. Sonochemical synthesis of hydroxyapatite from H3PO4 solution with $\mathrm{Ca}(\mathrm{OH}) 2$.J. Ultrasonics Sonochemistry, 8 (2001) 85-88.

[11] Van der Houwen J.A.M., Cresssey G., Cressey B.A., Valsami-Jones E.2003. The effects of organic ligands on the crystallinity of calcium phosphate. J. Cryst Growth, 249 ( 2003) 572 - 583.

[12] J. R. Long, W. J. Shaw, P. S. Stayton, and G. P. Drobny. 2001.Structure and dynamics of hydrated statherin on hydroxyapatite as determined by solid-state NMR .j. Biochemistry. 40 (2001)15451-15455.

[13] H., Nagadome, K., Kawano, Y., Terada.1993. Adsorption of human lysozyme onto hydroxyapatite.j. FEBS Lett, 317 (1993) 128-130.

[14] A, Zieba., G, Sethuraman., F, Perez., G.H, Nancollas., D, Cameron.1996. Influence of Organic Phosphonates on Hydroxyapatite Crystal Growth Kinetics .j. Langmuir ,12 (1996) 2853.

[15] L,Wu., F,Willis., P.W.,Schindler.1991. Synthesis and Characterization of Nanoapatites Organofunctionalized with Aminotriphosphonate Agents .J.ColloidlnterfaceScience,147 (1991)178-185.

[16] J.Portier., J.H.Choy., M.A.Subramanian.2001. Inoganic-organic-hybrids as precursors to functional materials.J.Inorg.Mater,3 (2001) 581-592.

[17] C, Drouet., J,Gomez-Morales., M, lafisco., S, Sarda.2012.in surface tailoring of inorganic materials for biomedical application. Bentham science.

[18] Chao, Qi., Qi-Li , Tang., Ying-Jie , Zhu., n, Xin-Yu ,Zhao., Feng, Chen .2012. Microwave-assisted hydrothermal rapid synthesis of hydroxyapatite nanowires using adenosine 5'-triphosphate disodium salt as phosphorus source. J. Materials Letters, 85 (2012) 71-73.

[19] Berti, L., Burley, G.2008. Nucleic acid and nucleotide-mediated synthesis of inorganic nanoparticles.j.Nat Nanotechnol ,3 (2008) 81-7.

[20] L, El Hammari., A, Laghzizil., A, Saoiabi., P, Barboux., M, Meyer.2006. Chemical modification of porous calcium hydroxyapatite surfaces by grafting phenyl phosphonic and phenylphosphite acids. J.Colloids Surf. A 289 (2006) 84-88.

[21] Wu Y, Ackerman JL, Strawich ES, Rey C, Kim HM, Glimcher MJ.2003. Phosphate ions in bone:Identification of a calcium-organic phosphate complex by 31P solid-state NMR spectroscopy at early stages of mineralization. 72 (2003) $610-626$.

[22] Y, Wu., J.L. Ackerman., H.M. Kim., C, Rey., A, Barroug., M.J. Glimcher.2002. Nuclear Magnetic Resonance SpinSpin Relaxation of the Crystals of Bone, Dental Enamel, and Synthetic Hydroxyapatites. J. Bone Miner. Res. 17 (2002) 472-480.

[23] K, Kandori., A, Fujiwara., A, Yasukawa., T, Ishikawa.1999. adsorption of myoglobin onto various synthetic hydroxyapatite particule .Colloid Surf. A. Physico- chem. Eng. Aspects 150 (1999) 161.

[24] A, Laghzizil., P, Barboux., A, Bouhaouss . 1993.Mixed ionic conductivities in sodium fluoroapatites .J. Solid State lonics, 67 (1993) 137-143

[25] W.P. Rothwell., J.S. Waugh., J.P. Yesinowski.1980. High-resolution variable- temperature 31P NMR of solid calcium phosphate. J. Am. Chem. Soc. 102 (1980) 2637.

[26] Zhaoyang , Lou., Qun . Zeng., Xiang, Chu., Fang , Yang., Duanwei , He., Mingli, Yang., Mingli , Xiang., Xingdong, Zhang, Hongsong, Fan.2012. First-principles study of the adsorption of lysine on hydroxyapatite $\left(\begin{array}{lll}1 & 0 & 0\end{array}\right)$ surface .J.

Applied Surface Science, 258 (2012) 4911- 4916.

[27] K,V. Vasavada., B.D. Ray., B.D. Nageswara Rao .1984.31P NMR lineshapes of beta-P (ATP) in the presence of $\mathrm{Mg} 2+$ and Ca2+: estimate of exchange rates. J. Inorg. Biochem. 21(1984) 323.

[28] J.P. Yesinowski., H. Eckert.1987 . High-Resolution Structural Insights into Bone: A Solid-State NMR Relaxation Study Utilizing Paramagnetic Doping .J. Am. Chem. Soc. 109 (1987)6274.

[29] J.L. Miquel., L, Facchini., A.P. Legrand., C, Rey, J. Lemaitre.1990 . Solid State NMR to Study Calcium Phosphate

Ceramics .J. Colloids Surf. 45 (1990) 427. 
[30] P, Judeinstein., C, Sanchez .1996. Hybrid organic-inorganic materials: a land of multidisciplinarity. J. Mater. Chem, 6 (1996) 511.

[31] Zolt'an Szab'.2008. Multinuclear NMR studies of the interaction of metal ions with adenine-nucleotides.J.

Coordination Chemistry Reviews. 252 (2008) 2362-2380.

[32] Russell. Rg ., Watts NB.,Ebetino FH, Rogers MJ.2008.Mechanisms of action of bisphosphonates: similarities and differences and their potential influence on clinical efficacy .J. Osteoporos Int 19 (2008) 733-759.

[33] M. Matthies., G. Zundel.1979. Nonenzymic hydrolysis of ATP-infrared investigations of intermolecular interactions. J. Inorg. Biochem. 10 (1979) 109- 123.

[34] K. Nakanishi., A. Hashimoto., T. Pan., M. Kanou., T. Kameoka. 2003 .Midinfrared spectroscopic measurement of ionic dissociative materials in the metabolic pathway.J .Appl. Spectrosc. 57 (2003) 1510-1516.

[35] M. Matthies., G. Zunde .1977. Hydration and self-association of adenosine triphosphate, adenosine diphosphate, and their $1: 1$ complexes with magnesium (II) at various $\mathrm{pH}$ values: infrared investigations. J. Chem.Soc., Perkin Trans., II (1977) 1824- 1830.

[36] L, El Hammari., A, Laghzizil., P, Barboux., A, Saoiabi., K, Lahlil .2004. Crystallinity and fluorine substitution effects on the proton conductivity of porous hydroxyapatites.J. Solid State Chem. 177 (2004) 134.

[37] A, Laghzizil., P, Barboux., A, Bouhaouss.2000. Cationic conductivity and structural studies in the Pb8 K2-x Nax (PO4 )6 system Solid State Ion. 128 (2000) 177. 